\title{
Changing politics, changing language
}

\author{
The effect of institutional and communicative changes on political \\ language measured through content analysis of Italian intra-party debates
}

\section{Andrea Ceron \\ Università degli Studi di Milano}

This paper examines the changes in political language that occurred after 1989 in Italy and focuses on textual documents drafted by intra-party subgroups between 1946 and 2010 that were related to the internal debates of Italian political parties. These documents, which are addressed to party members and activists rather than the wider public, have been analyzed through quantitative text analysis of word frequencies. The results confirm that a few relevant changes occurred that involve the lexicon, tone, and content of messages. However, concepts such as left and right are still relevant, and we observed neither a strong decline in the use of ideological terms nor a wider usage of populist words. Despite the growing personalization of politics, the main political leaders are not frequently mentioned, with two exceptions: Prodi and Berlusconi. Overall, there is a distance between intra-party politics and the logic of entertainment.

Keywords: ideology, leadership, populism, text analysis, lexicon, left-right

\section{Introduction}

A number of Western democracies experienced cultural and institutional changes after the Cold War related to the decline of ideology or to political system reforms. These changes, together with the increasingly important role played by news media and new media, appear to be responsible for the 're-semanticisation' 
(Hasan 2003) as well as the personalization and 'spectacularization' (Mazzoleni and Schultz 1999; Patterson 1993) of political communication, which dramatically altered political language.

However, these changes in the use of language should have affected mainly oral communication and speeches delivered on television or during party rallies, i.e., when a speaker is attempting to establish a direct connection with citizens. Given the nature of these adjustments and the de-ideologization and mediatization of politics, we would expect to observe fewer changes in written communications intended for skilled or partisan audiences.

Although certain scholars have revealed the existence of such dynamics by focusing on oral speeches (e.g., Gualdo and Dell'Anna 2004), little attention has been paid to written texts and, in particular, to those addressed to partisan audiences attending party conferences (Ceron 2015). To fill this gap, we focus on intraparty debates and examine whether political and institutional changes have altered language usage.

For this purpose, we gathered documentation related to the 'contested congresses' of Italian parties from 1946 to 2010. We collected 254 texts and applied quantitative text analysis to compare word usage before and after the beginning of the Italian transition, focusing on the lexicon (changes in the relative frequencies of words over time) and acceptation (changes in the political meaning attached to words).

The analysis reveals that political language has undergone some changes. However, references to ideology persist, suggesting that the ideological left-right cleavage still plays a role, at least in intra-party debates (Ceron 2012). Moreover, the phenomenon of personalization has only marginally altered the political language used in intra-party documents. When the party 'talks to itself', it addresses members and activists by using traditional ideological heuristics that are largely unaffected by the logic of spectacularization.

The paper is organized as follows. The first section summarizes the literature on changes in political language and provides a theoretical framework. The second section describes the data analyzed and the technique adopted for such analysis. The third and fourth sections present the results and draw conclusions. 


\section{Changing politics, changing language: A theoretical framework}

1.1 Literature and theoretical background

A number of scholars argue that ideology seems to have lost its grip on Western democracies (e.g., Bell 1988). These claims were strengthened at the end of the Cold War, when some scholars spoke about the end of history (Fukuyama 2006), whereas other scholars suggested that the divisions between left and right had become blurred (Fairclough 2000: 110; Giddens 1994).

The declining role of ideology - together with the cultural and institutional changes that occurred in the early 1990s and the increasingly important role played by the news media - altered the use of political language and fostered the personalization and 'spectacularization' of political communication (Mazzoleni and Schultz 1999; Patterson 1993) and the 're-semanticisation' of language (Hasan 2003).

During electoral campaigns and everyday politics, political leaders - as opposed to ideological commitments and symbols - garner the lion's share of attention (Campus 2002), and political communication has begun to rely on populist arguments (Blumler and Kavanagh 1999) to compensate for the diminished role of ideology. These features go hand in hand with language simplification and recourse to emotional themes (Richards 2004). Politicians abandon the use of political jargon in their messaging and increase the participation and involvement of wider audiences (Fedel 2003).

Regarding Italy, scholars agree that the downfall of communism in 1989 was the actual starting point of the transition that eventually gave birth to the Second Italian Republic (Bull and Rhodes 1997; Lyttelton 2009). The transition was strengthened by the 1993 electoral reform, which changed the electoral system from open-list proportional representation to a mixed system with $75 \%$ of seats assigned in single-member districts. After five years of transition (1989-1994), the political system and the nature of Italian politics were completely modified. Bipolar competition and alternation in power were enhanced, albeit at the expense of the fluidity of the party system (Ceron 2015). The entrance of new parties brought new issues to the political agenda. The development of mass media, the birth of 'personal parties' led foremost by politicians and personalities, and the new electoral rules stressed the idea of politics as a horse race (Mazzoleni 1991; 
Patterson 1993), which led to more a personalized style of political communications that was focused on the personalities of individual party leaders (Campus 2002, 2010; Mazzoleni 1987).

The Italian transition altered the use of political language accordingly. Indeed, several studies attest that political language, and particularly its lexicon, was transformed simultaneously with the changes in Italian politics (Croci 2001; Gualdo and Dell'Anna 2004; Lyttelton 2009; McCarthy 1997). The old political jargon (called politichese), which was meant to address a limited audience consisting of insiders, was replaced by a new popular and sometimes obscene language (gentese) that mimicked the language of common people (Croci 2001; Lyttelton 2009). The lexicon was enriched by terms from other semantic fields, such as sports, war and religion, in addition to Anglophone words (Jačová 2011; Lyttelton 2009; Semino and Masci 1996). The usage of terms related to topics such as Europe, justice and ecology, which had become salient in the policy agenda, increased (Bernardi and Tuzzi 2007; Jačová 2011). After the transition, political language lost its ideological connotation (Jačová 2011) and became increasingly focused on candidatecentered personalization (Campus 2002) up to the point that the word 'party' largely disappeared from the political debate.

Empirical analyses confirmed this general picture, although they focused on highly visible oral speeches (e.g., Gualdo and Dell'Anna 2004; Campus 2002) or on political language as a whole (i.e., oriented to the wider voting public). Conversely, little attention was paid to changes in written text, particularly those texts related to intra-party debates addressed to a partisan audience. Our research question focuses on this latter type of communication.

\subsection{Research question}

Party factions play a crucial role in many political systems and particularly in Italian politics. They affect government formation and duration as well as parliamentary lawmaking (e.g., Ceron 2012, 2015). Both in the First and Second Republics, a high level of factionalism characterized Italian parties. Given such strong heterogeneity, factions typically fight to take control of the organization or bargain to find a compromise. Party congresses thus become crucial arenas in which struggles and negotiations occur. 
It is well known that intra-party politics is a type of 'invisible' politics that occurs in the shadows. Although the outcome of the debates held during party conferences and congresses is usually published and available, the related documentation is not typically released to the wider public. ${ }^{1}$ Instead, these documents are directed to insiders - ideologically oriented party members and activists - and they are rarely broadcast by the media. This is particularly true with respect to congress motions, i.e., omnibus policy documents that are presented by rival factions and discussed during the party congress to shape party strategy and ideology. Given their nature, congress motions are written texts with limited attention in the media because they are only publicized through party websites and newspapers.

As such, we argue that the theoretical framework that links the declining role of ideology and the spectacularization and mediatization of political communication to changes in political language may not apply in this context.

RQ: Do changes in political language related to the decline of ideology and the mediatization of politics affect the domain of intra-party politics?

\section{Quantitative text analysis of congress motions}

To answer our research question, we collected documentation related to the 'contested congresses' of Italian parties from 1946 to $2010 .^{2}$ Motions were gathered either from records of official proceedings or from parties' newspapers, magazines and websites. Overall, we collected 254 texts related to 83 congresses and 18 different parties (see Table 1). Although data about a few congresses are missing, we were able to find information regarding $70 \%$ of the contested congresses held by parties that were included in the analysis.

Our dataset included a total of $1,429,258$ words and is sufficiently large to provide valid results. ${ }^{3}$ Moreover, the dataset includes information related to parties that cover the entire left-right spectrum. For the first period (pre-1989), our dataset covers parties ranging from the left-wing Italian Socialist Party of Proletarian Unity to the post-fascist Italian Social Movement (MSI). For the second period (post-1989), our dataset includes motions from the far-left PRC (heir of the Italian Communist Party) to the right-wing National Alliance (heir of the MSI). 
Table 1. Details on number of congresses, motions and words per motion

\begin{tabular}{llllll}
\hline Label & Party & $\begin{array}{l}\text { Congresses } \\
\text { analyzed }\end{array}$ & Missing & Motions & $\begin{array}{l}\text { Words per } \\
\text { motion }\end{array}$ \\
\hline AN & National Alliance & 1 & 0 & 4 & 4,794 \\
DC & Christian Democracy & 11 & 2 & 41 & 3,642 \\
DS & Democrats of the Left & 4 & 0 & 12 & 10,506 \\
FV & Greens Federation & 2 & 14 & 6 & 2,665 \\
MSI & Italian Social Movement & 5 & 2 & 20 & 8,282 \\
NPSI & New Italian Socialist Party & 2 & 0 & 4 & 7,281 \\
PCI & Italian Communist Party & 3 & 0 & 8 & 10,066 \\
PD & Democratic Party & 1 & 2 & 3 & 9,345 \\
PDA & Action Party & 1 & 1 & 3 & 434 \\
PDCI & Italian Communists Party & 1 & 0 & 2 & 12,080 \\
PLI & Italian Liberal Party & 11 & 0 & 35 & 3,486 \\
PRC & Communist Party - Refounding & 6 & 0 & 20 & 11,423 \\
PRI & Italian Republican Party & 11 & 4 & 25 & 970 \\
PS & Socialist Party & 1 & 0 & 3 & 5,442 \\
PSDI & Italian Socialist Democratic Party & 9 & 12 & 25 & 4,160 \\
PSI & Italian Socialist Party & 12 & 0 & 38 & $6, .820$ \\
PSIUP & Italian Socialist Party of Proletarian Unity & 1 & 0 & 3 & 5,181 \\
UDC & Union of Centre and Christian Democrats & 1 & 0 & 2 & 10,017 \\
Total & & $\mathbf{8 3}$ & $\mathbf{3 7}$ & $\mathbf{2 5 4}$ & $\mathbf{5 , 6 2 7}$ \\
\hline
\end{tabular}

The analysis was conducted using Wordfish, an automated technique of quantitative text analysis (Slapin and Proksch 2008; Proksch and Slapin 2009). ${ }^{4}$ Wordfish is an automated scaling model whose primary function is to estimate the policy position of political actors by comparing word frequencies across documents. By doing so, Wordfish also enables the extraction of useful information to analyze the political language used by those actors. We know that politicians typically calculate each word included in a political text not only with respect to some institutional and relevant speeches, such as those delivered by heads of state (Bolasco et al. 2006; Cortelazzo and Tuzzi 2007), but also with respect to party manifestos and congress motions. ${ }^{5}$ The following anecdote illustrates how relevant the inclusion or exclusion of any single word can be: During the third party congress of the Democratic Party in 2009, moderate politicians that opposed Pierluigi Bersani claimed that the party would have become social-democratic if Bersani had been elected its leader. The party president, Rosy Bindi, who supported Bersani, responded that the word 'socialdemocracy' does not appear in Bersani's motion. ${ }^{6}$

Following this perspective, Wordfish analyzes all the single words contained in a document and assumes that the relative frequency of each word is informative about the political position of a text when compared to other texts. ${ }^{7}$ Then, it compares word usage across documents and provides estimates of the positions of political actors, arranging documents and words along a latent dimension. ${ }^{8}$ This latent dimension 
captures catches the political meaning of texts submitted to the analysis. Given that motions are comprehensive documents that portray the ideological orientation of the party, it is fair to interpret this latent dimension as a classic ideological left-right scale.

The Wordfish algorithm estimates four main parameters. Two of these parameters provide information about the length $(\alpha)$ of each text and its position $(\omega)$ on the latent dimension. The other two parameters provide information about word usage and the 'discriminating power' of each term that can be exploited to analyze the language. In detail, it evaluates the average frequency of each word in all the documents $(\psi)$ and estimates their 'discriminating power' $(\beta)$, which corresponds to the word's ideological position. These values are displayed in Figure 1. For each word, a higher absolute value of $\beta$ indicates that such a word is used more frequently in right-wing or left-wing texts and, therefore, is more informative in discriminating among documents. Accordingly, these words will be located on the extremes of the scale. Conversely, words that are used evenly in documents (e.g., very common words, such as articles and prepositions) retain a lower discriminating power and are placed in the middle of the scale. For instance, words such as 'politics' (politica), 'Italians' (italiani), and 'taxes' (tasse) are widely used by all party factions, and their discriminating power is therefore close to zero. Other words retain a lower average frequency but are more helpful in distinguishing right-wing and left-wing texts. Although every subgroup talks about taxes, factions in right-wing parties may declare the intention to cut taxes to promote 'disinflation' (disinflazione), and left-wing party factions may want to change taxation to reduce 'unemployment' (disoccupazione). In this vein, 'disinflation' will be considered a right-wing word, and 'unemployment' will characterize left-wing documents. Figure 1 highlights the policy position of words related to the age before (black) or after (gray) the Italian transition and captures the actual meanings of leftwing and right-wing words (Dyrberg 2003). For instance, the words 'God' (Dio), 'motherland' (patria) and 'family' (famiglia), which are typically associated with right-wing values, have been recognized as rightwing words. Conversely, 'solidarity’ (solidarietà), 'class' (classe), and 'nationalization' (nazionalizzazione) are correctly identified as left-wing terms. In addition to the economic dimension, this distinction also seems to cover issues related to other types of policies. For instance, the left is concerned with 'laity' (laicità) and 'disarmament' (disarmo), and the right is concerned with 'crime' (criminalità), 'soldiers' (soldati) and 'Islamization' (islamizzazione). 


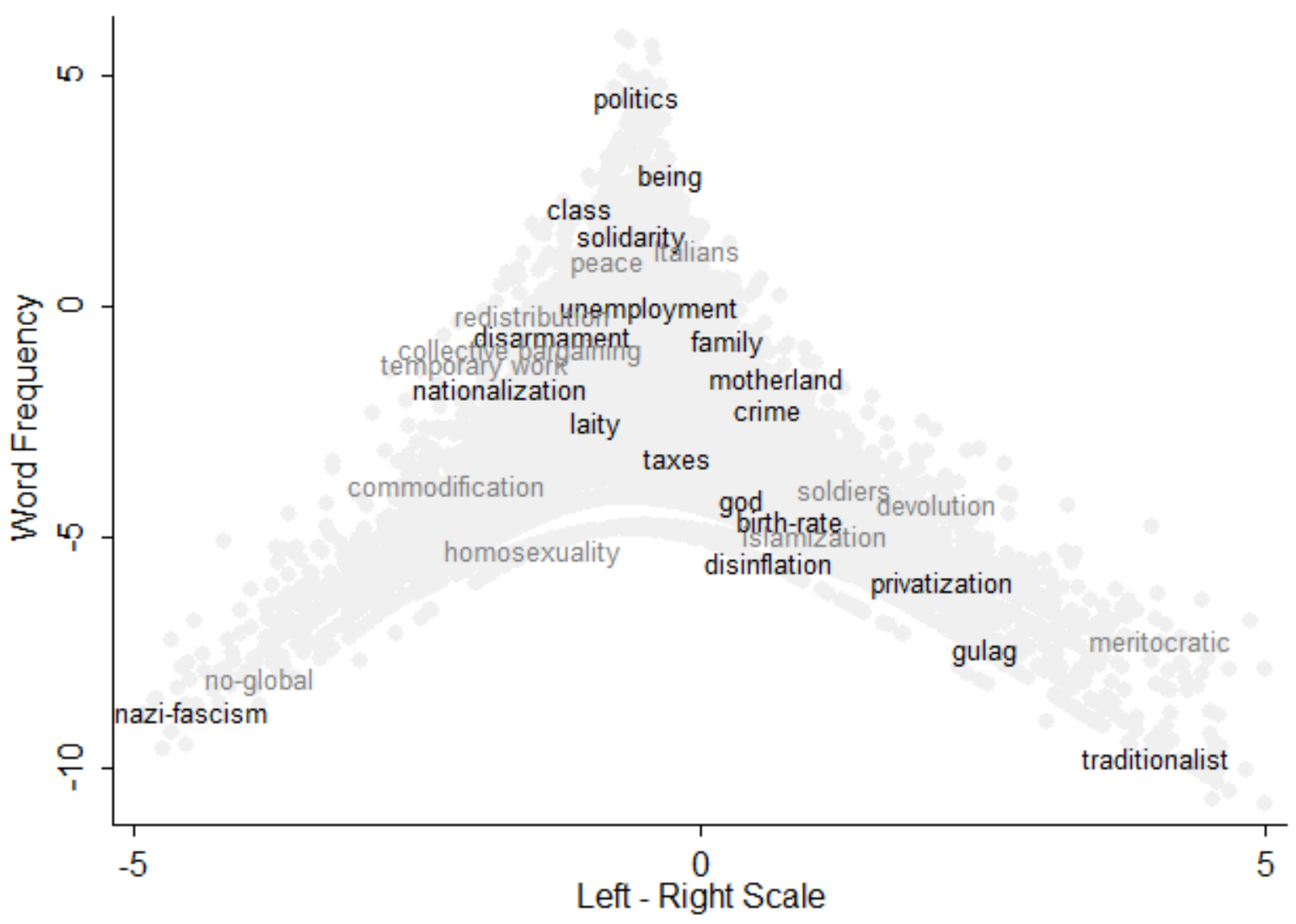

Figure 1. Frequency $(\psi)$ and policy position $(\beta)$ of each word before (black) and after (gray) the beginning of the Italian transition.

In the next section, we will assess how word usage has been modified over time. We proceed by comparing the frequencies $(\psi)$ of words used before and after $1989 .{ }^{9}$ We then detect and examine words whose political meanings $(\beta)$ changed before and after the transition and shifted from the left to the right of the spectrum (or vice versa).

\section{Changes in political language in the wake of the Italian transition}

In this empirical section, we will examine several subjects that were discussed in the theoretical section. We begin by assessing how language has changed, focusing on new topics (e.g., Europe or the environment) that have entered into the political agenda. 
Second, we test how changes in the rules of the game reframed the discussion around the emerging political actors. In particular, we investigate the effects produced by the 'personalization' and 'presidentialization' of politics, focusing on the role of leadership, the decline of ideology, and the appeal to populist arguments. In so doing, we test our research question and assess whether the role of ideology has been replaced by references to leaders and populist words.

To conclude, we examine other adjustments in the lexicon, such as neologisms and terms that were regularly used by Silvio Berlusconi, in particular, and we highlight how the political meanings of some words have changed across time, shifting to the left or to the right after 1989.

Overall, we observe that the language used in modern congress motions is not necessarily poorer. In fact, we count 32,585 unique words before 1989 and 35,391 unique words after 1989, which indicates that the language grew richer after the beginning of the transition, which might be due to the adoption of foreign terms and neologisms that increase the variety of the language. Nevertheless, only 2 or 3 percent of these unique words are used at least once in each document. Thus, the Italian language seems to consist of no more than 1,000 basic words, and certain other terms are more particularly associated with certain political groups.

\subsection{New issues, new language}

First, we examine how new issues introduced to the policy agenda might alter the use of political language. Figure 2 displays the normalized average frequency of words related to new topics. 


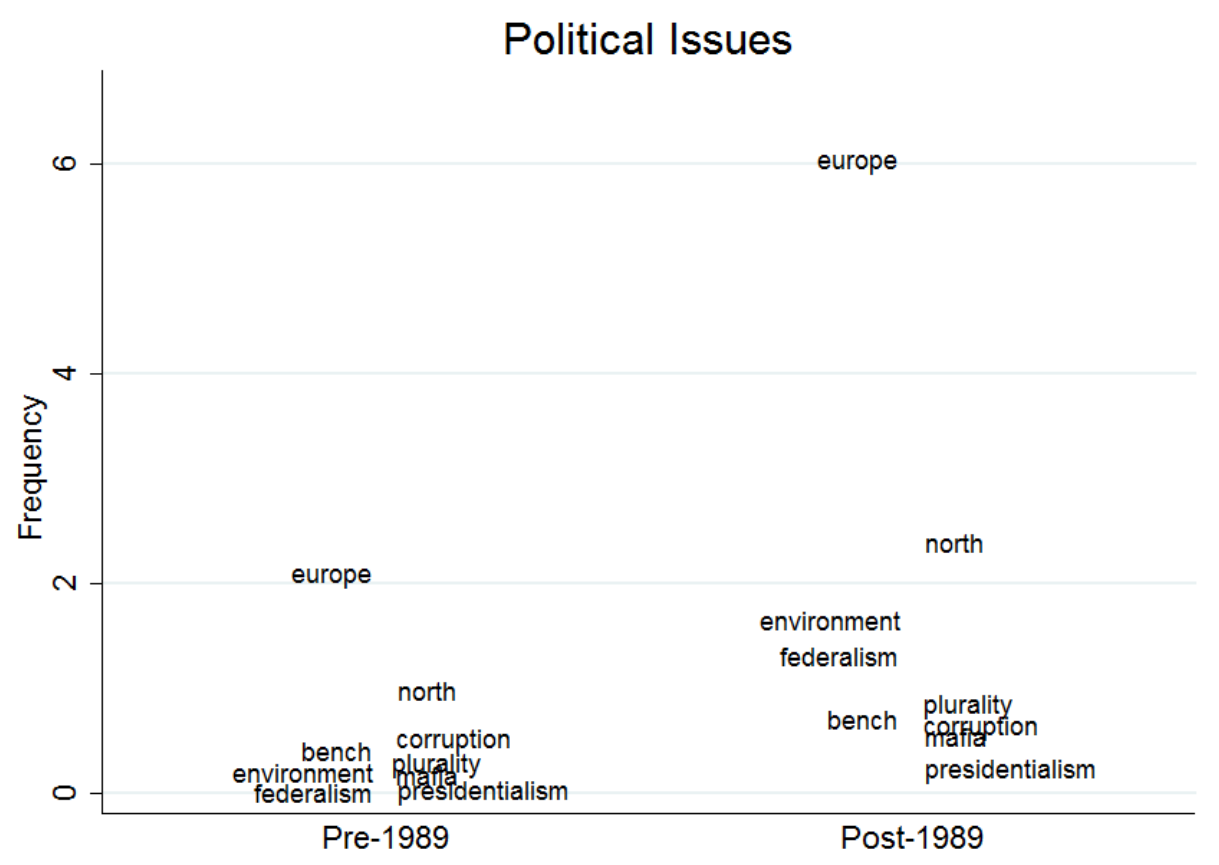

Figure 2. Normalized average frequency of words related to new issues in the policy agenda. Comparison between the first (pre-1989) and second periods (post-1989).

The Europeanization of politics (Franchino and Radaelli 2004) was one of the most important issues entering the agenda in the middle of the Italian transition - when the Maastricht treaty was signed - and this Europeanization trend had a substantial effect on political communication (Della Porta and Caiani 2007; Jačová 2011). Since Maastricht, all political parties must now consider the European Union as both a political actor to deal with and an issue on which they must take a position. When examining congress motions, we observe a striking growth of all the terms related to this subject. For example, in Figure 2, we notice that the use of the word Europa increased dramatically. The growth is so notable that this word became one of the most commonly used words after 1989.

In turn, the saliency of the environmental issue emerged in the 1980s and was later reinforced due to environmental movements and the Green party (created in 1990). During intra-party conferences and in parliamentary debates, references to the environment increased (Curini and Martelli 2009, 48). The frequency of words such as 'environment' (ambiente) and 'ecology' (ecologia) increased, which was also the case with respect to words containing the terms ambient* or $e c o l *$ in the root (Jačová 2011). 
On a similar note, the North-South cleavage became important at the end of the 1980s, when regionalist and autonomist parties emphasized the issue of devolution and subsidiarity. In 1989, these movements merged to create a new party, the Northern League (LN), which supported the Northern regions against the state. The large share of votes won by the LN pushed all the other parties to address the question of devolution. Accordingly, references to words such as 'North' (Nord) and 'federalism' (federalismo) strongly increased after $1989 .^{10}$

Another issue, partly related to the concepts of devolution and federal reform, concerns constitutional reform more generally. Since the 1980s, several attempts have been made to modify the constitution and the rules of governing through referenda or in legislative commissions. These attempts followed two different paths. On the one hand, they attempted to modify the electoral system and introduce plurality districts to increase accountability. On the other hand, some proposals were intended to increase the power of the prime minister and transform Italy into a presidential or semi-presidential republic. Figure 2 confirms that reforms were largely discussed within the parties, as shown by the growing use of the words 'plurality' (maggioritario) and 'presidentialism' (presidenzialismo).

Another event was deeply rooted in the Italian transition and altered the everyday agenda: the corruption scandal referred to as Tangentopoli ('Bribesville'). In 1992, the beginning of the judicial inquiry, called Mani Pulite ('Clean Hands'), shed light on the link between politics and business and revealed that the party system was permeated by corruption. This inquiry, together with the end of the Cold War, generated incentives for valence competition (Curini and Martelli 2009). Consequently, the use of words with the root corru* $^{*}$ or corrot* (as in corruzione, meaning corruption) increased. Party factions made several references to such topics as corruption and honesty, which became increasingly important to the agenda. However, this issue was largely discussed during intra-party debates because it was directly linked with valence competition and party strategy. The same reasoning holds for judicial reform and the role of the 'bench' (magistratura). The judiciary became an important actor during the Second Republic, when it was involved in a struggle with the former prime minister, Silvio Berlusconi, leader of the center-right coalition (Ceron and Mainenti 2015). Finally, after the mafia massacres of 1992-1993, use of the word mafia grew. ${ }^{11}$ 


\subsection{New actors}

The Italian transition has changed the rules of governing by altering the political system and its main actors. The electoral law was reformed in 1993 and transformed the Italian government into a mixed system with $75 \%$ of MPs elected in single-member districts. In 2005, a new reform introduced closed-list proportional representation with a majority prize for the first ranking party and therefore forced coalitions to select and nominate their leaders before the elections. These reforms reshaped party competition, reducing the importance of political parties in favor of local candidates, coalitions, and leaders, and campaign styles changed accordingly. The personalization of politics became so widespread that 'personal parties' tied to popular and charismatic leaders appeared. The parliament was a key actor during the First Republic, but its centrality was lost in the transition, and the government strengthened its agenda power, becoming more relevant. Figure 3 confirms this path.

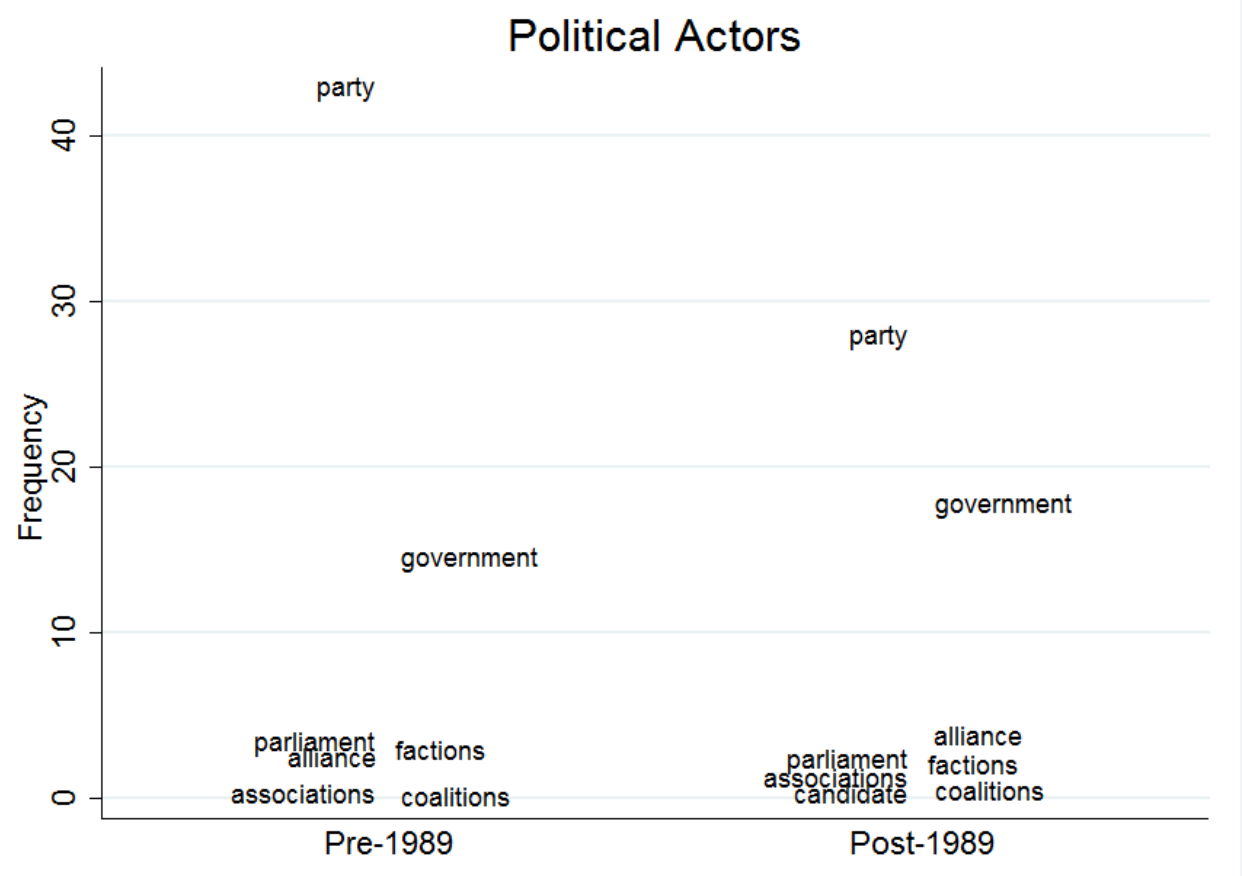

Figure 3. Normalized average frequency of words related to the main institutional actors of Italian politics. Comparison between the first (pre-1989) and second periods (post-1989).

The word 'parliament' (parlamento) is mentioned less than in the past, whereas references to the 'government' (governo) have increased. Similarly, the frequency of the word 'coalitions' (coalizioni) 
grew as use of the term 'party' (partito) decreased. Although we analyze debates held in party congresses, the frequency of this word decreased after the transition. On the one hand, the use of the term 'party' decreased because the party became a less pivotal actor; on the other hand, communication strategies modified the term in an attempt to detach communications from the idea of 'partitocracy' and to run the elections under a new attractive label. Italian parties began defining themselves using other terms, such as 'alliance' (National Alliance), 'movement' (Five Stars Movement), 'union' (Union of Centre and Christian Democrats), 'league', ‘federation', 'pact', 'list' (Dini's List and Di Pietro's List), and 'people' (People of Freedom). Other parties were named only through popular and new adjectives or nouns, such as Forza Italia, La Rete (the Net), and La Margherita (the Daisy) as well as the Italian Socialists, Left Ecology and Freedom, The Right, Great South, Civic Choice (created by the former premier Mario Monti), Brothers of Italy, and Civil Revolution. Only a few parties have kept the term 'party' in their names (e.g., Democratic Party or Italian Communists' Party). Similarly, a number of intra-party subgroups began to refer to themselves as 'associations' (associazioni) or 'foundations' (fondazioni) rather than 'factions' (correnti). However, despite their decreased usage, the terms 'party' and 'factions' are still mentioned in congress motions, indicating that the concepts have not disappeared.

\subsection{Leadership and ideology}

The personalization of politics is also reflected in the growing use of words such as 'candidate' (candidate) and leader, to the extent that in 2008 and 2013, nearly every party included the name of its leader in its logo to exploit the leader's popularity. The leadership of a party is a cognitive shortcut affecting voting behavior. Ideology is another. On the one hand, we want to test whether factions are increasingly mentioning party leaders in congress motions. On the other hand, we want to observe whether factions still rely on ideology as a device to mobilize their supporters and win the votes of party members and activists. 


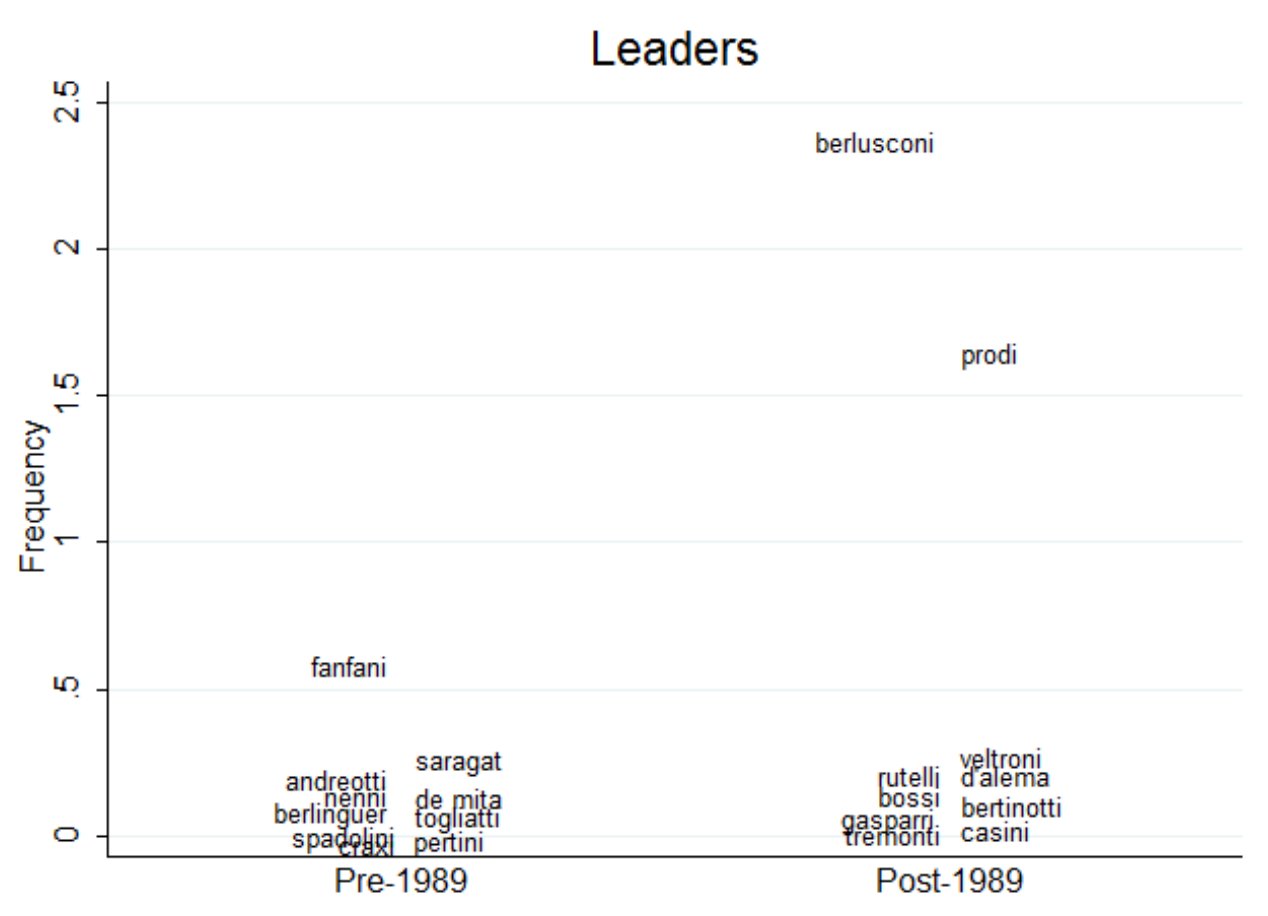

Figure 4. Mentions of political leaders. Comparison between the normalized average frequency in the first (pre-1989) and second periods (post-1989).

After the transition, we record an overwhelming number of citations related to Prodi and Berlusconi, the leaders of the center-left and center-right coalitions throughout the Second Republic, respectively (see Figure 4). Surprisingly, all the other post-transition party leaders (Bertinotti, Bossi, Casini, D'Alema, Gasparri, Rutelli, Tremonti e Veltroni) were mentioned at the same rate as their pre-1989 counterparts (Andreotti, Berlinguer, Craxi, De Mita, Fanfani, Nenni, Pertini, Saragat, Spadolini). In light of the foregoing, it seems that the language of intra-party politics is partially affected by personalization because only Prodi and Berlusconi were repeatedly mentioned in intra-party debates.

In regard to ideology, only a few terms were dropped (such as 'socialism', socialismo, and 'democracy', democrazia). The frequency of 'Marxism' (marxismo), 'Catholicism' (cattolicesimo), and 'liberalism' (liberalismo) was stable over time, and we did not observe a drastic reduction in the use of words with ideological valence. Although some authors claim that concepts such as 'left' (sinistra) and 'right' (destra) became meaningless (Giddens 1994), these two words have been mentioned more frequently post-1989, as shown in Figure 5. Despite several institutional and political changes, it seems that factional 
motions are not more likely to primarily mention politicians, and ideology is still important in intra-party competition.

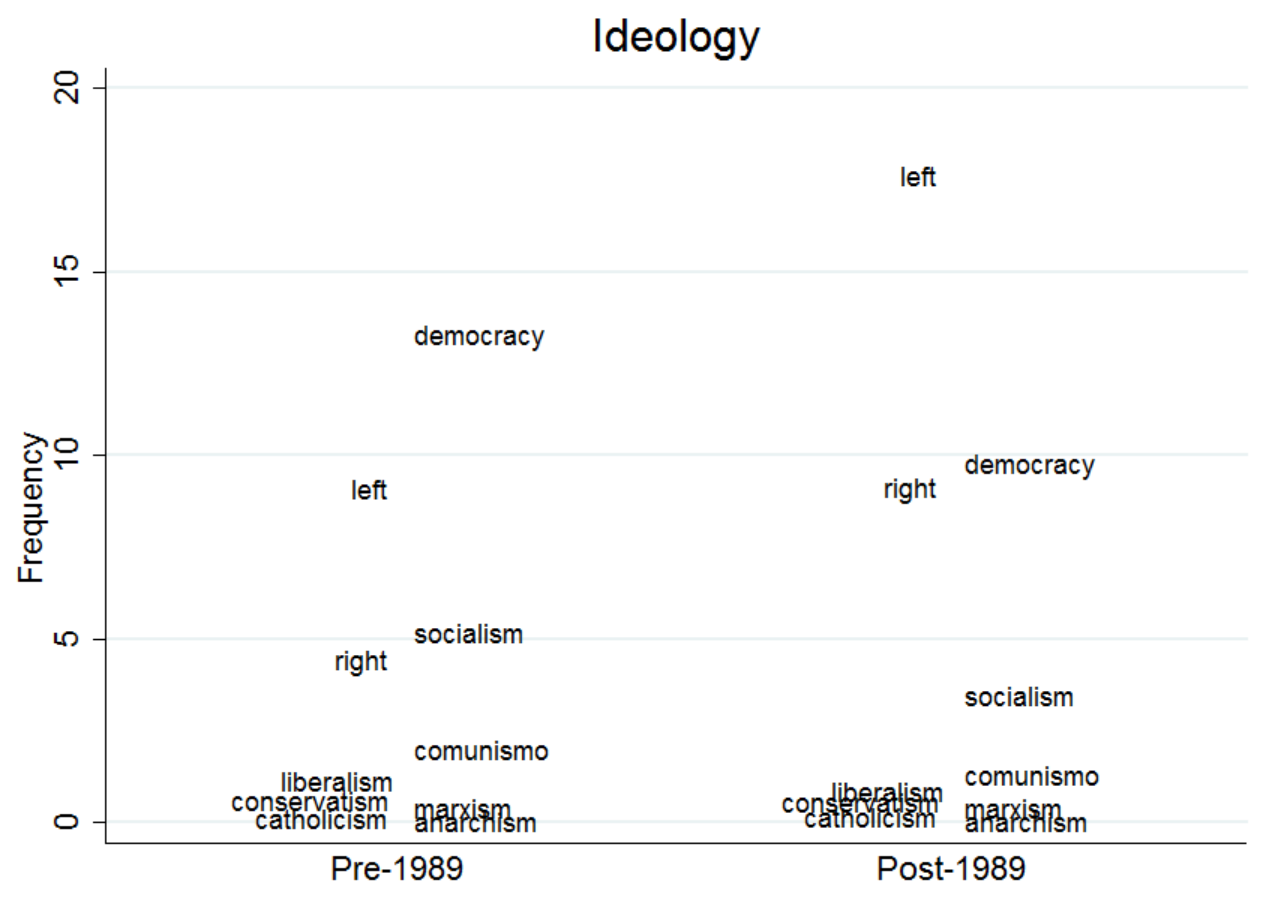

Figure 5. Normalized average frequency of words related to ideology. Comparison between the first (pre1989) and second periods (post-1989).

\subsection{Populist words}

It has been argued that the decline of ideology has fostered the use of populism as a substitute. Although ideology has not disappeared from intra-party documents, we can assess whether the usage of populist words has increased by referring to a list of 'populist' words suggested by the literature (Rooduijn and Pauwels 2011). In Figure 6, we display the pre- to post-1989 difference in the frequency of terms whose root is linked to populist words. ${ }^{12}$ Positive values attest that usage increased after the beginning of the transition: the frequency of 11 out of the 16 words has grown. The extent of this growth, however, seems small, and in five cases, we even observe a reduction in the use of populist terms. Populist words were (slightly) more common in right-wing party debates before 1989 , whereas they have tended to be used more frequently by left-wing parties since the transition. However, their discriminating parameters $(\beta)$ are not extreme, given that both wings included these terms in their documents (see also Figure 10 below). 
Overall, the use of populist words has increased in recent years, but the difference is irrelevant. This result, together with the continuing role of the left-right divide and the recourse to ideological terms, strengthens the idea that within internal debates, parties have not abandoned their traditional language when appealing to the rank-and-file. They are less prone to using anti-political words that might be more attractive to the general public consisting of voters and citizens.

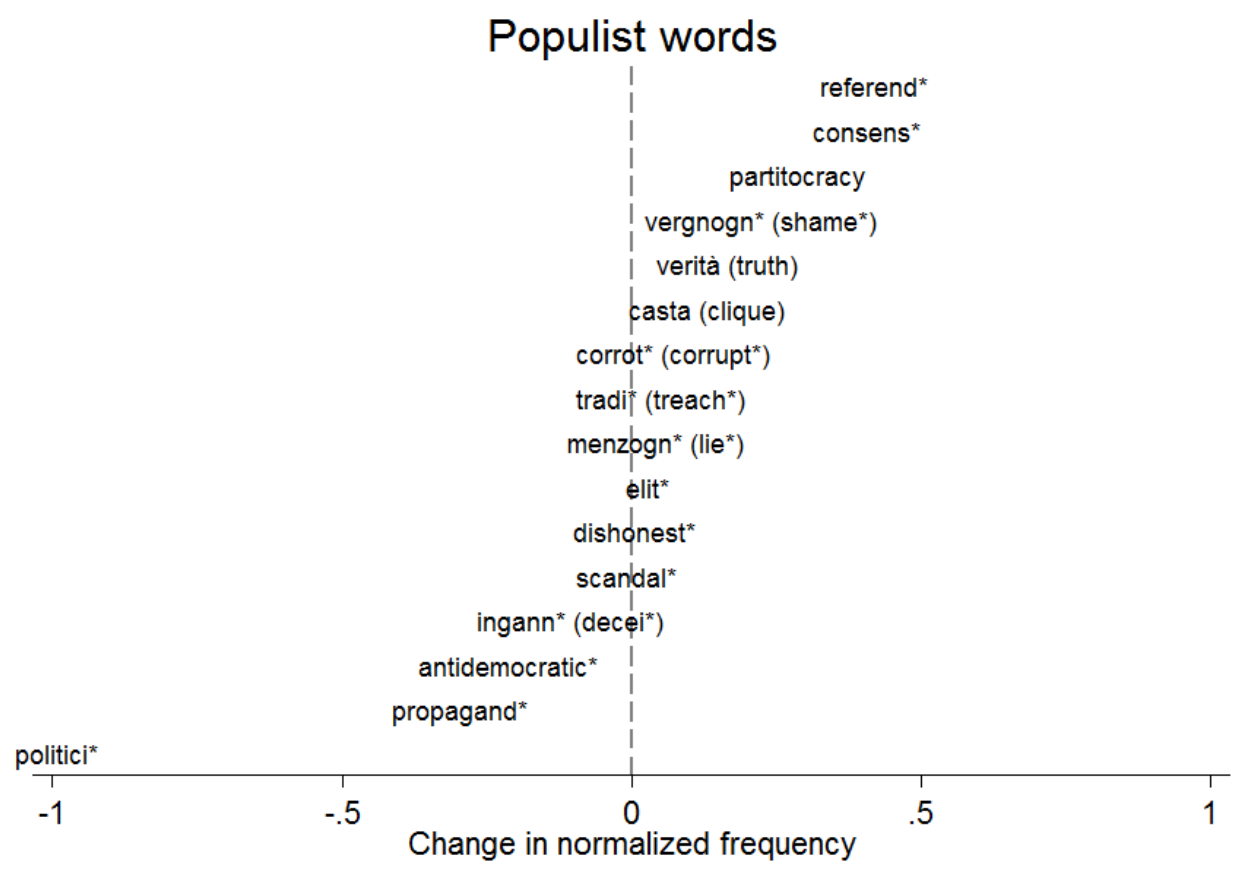

Figure 6. Normalized average frequency of 'populist' words. Comparison between the first (pre-1989) and second periods (post-1989).

\subsection{New lexicon}

In addition to changes in the political language related to institutional reforms or the policy agenda, figures 7 and 8 present the evolution of linguistic styles, focusing on the lexicon. At the outset, we observe that the lexicon seems to have been contaminated by neologisms and foreign terms. We report an increasing use of English words, such as 'welfare' in lieu of the Italian stato sociale, as well as 'antitrust' and 'boom'. Some words (privacy and authority) appear for the first time only after 1989, which contrasts with the idea that political language has abandoned the technicalities of the political jargon in favor of a simpler lexicon. However, the meaning of these Anglophone words should be easily understandable by party members. 


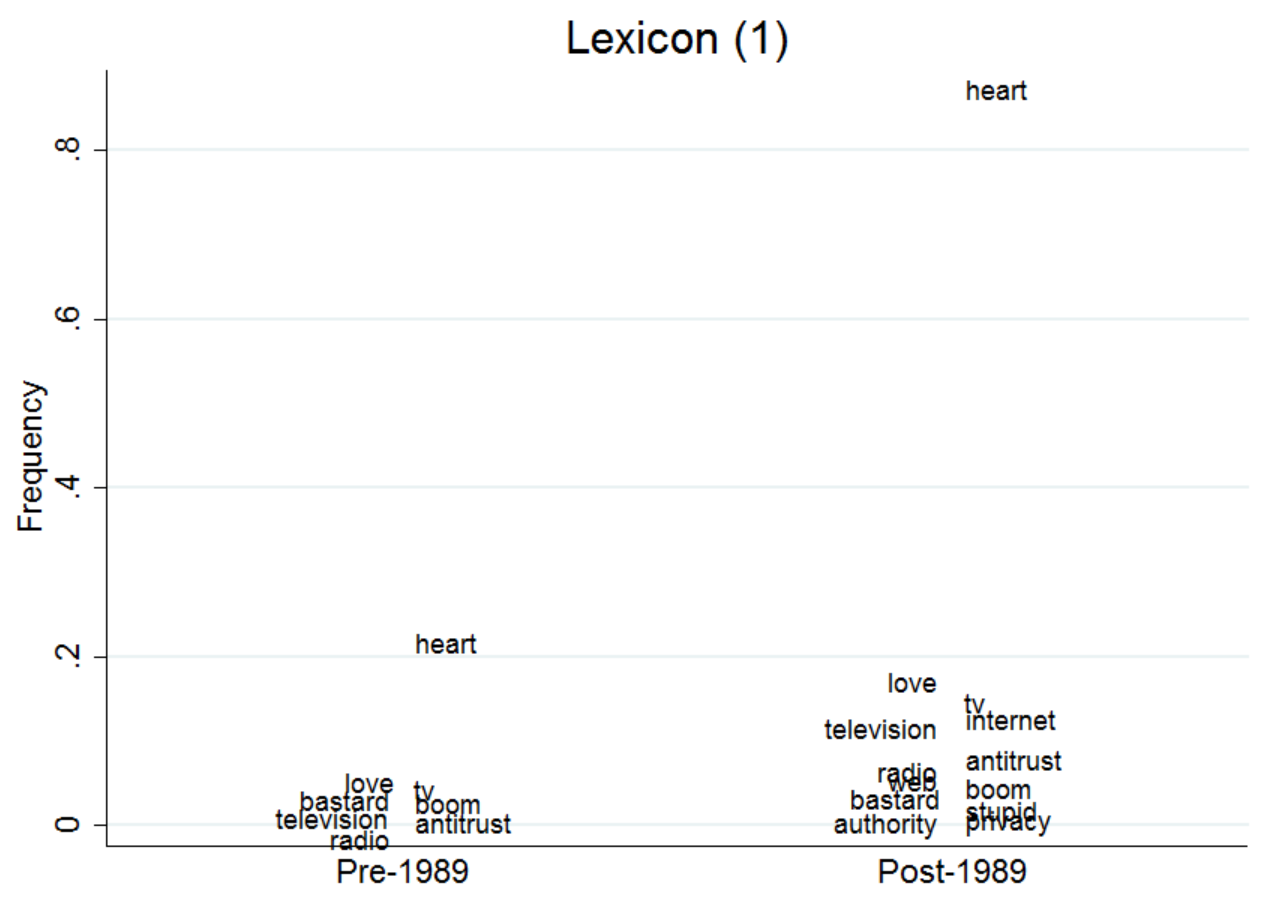

Figure 7. Change in political lexicon. Comparison between the normalized average frequency of some words in the first (pre-1989) and second periods (post-1989).

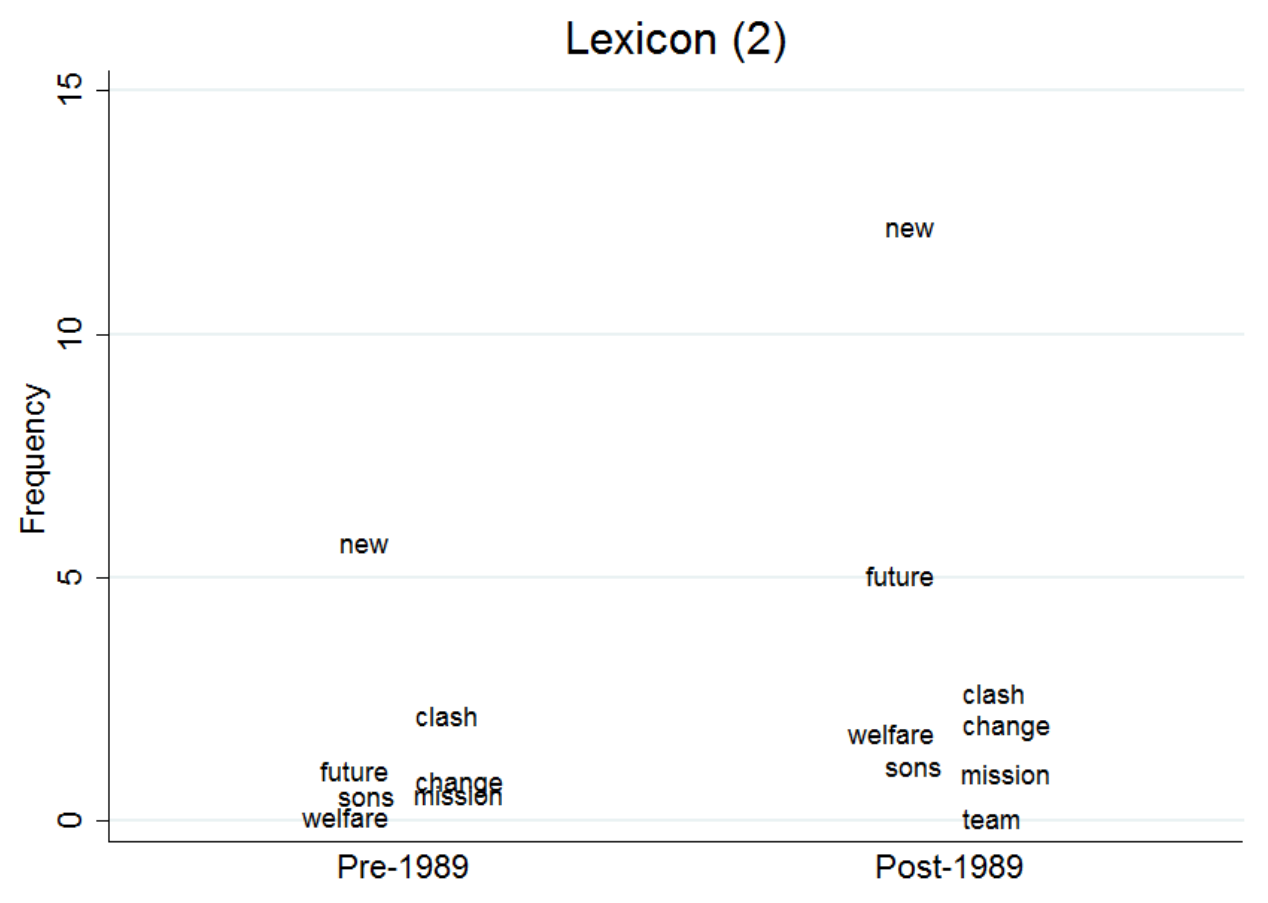

Figure 8. Change in political lexicon. Comparison between the normalized average frequency of some words in the first (pre-1989) and second periods (post-1989). 
Congress motions confirm the growing usage of emotional terms (e.g., 'love' or amore and 'heart' or cuore), as has been witnessed in other contexts (Richards 2004). The same applies to analogies coming from other semantic fields, such as sports and military or religious jargon (Semino and Masci 1996). The frequency of words such as 'team' (squadra), 'clash' (battaglia), 'mission' (missione), and 'warrior' (guerriero) is higher after $1989 .{ }^{13}$ Colorful language is nearly absent, although the use of certain terms is reported ('stupid' or stupid, and 'bastard', bastardo). Additionally, references to mass media (televisione and radio) are high. In the second period, the web becomes a main character. Overall, mentions of internet nearly equal those of 'television' $(t v)$.

The last political novelty both in rhetoric and lexicon is the 'old-new' juxtaposition (Bolasco et al. 2006). Due to the crisis of the First Republic, Italian parties sought to renew their images. They attempted to present themselves under a shadow of freshness using the terms 'new' (nuovo), 'change' (cambiamento), and 'future' (futuro). They were oriented toward the future and focused on providing opportunities for our 'sons' (figli). Future and Freedom (FLI), a political party created in 2010, includes the word 'future' in the label, which is emblematic of this trend.

\section{6 'Berlusconian’ words}

Most of the changes discussed thus far are linked to Berlusconi's arrival on the Italian political scene, and it is not surprising that he is the most frequently mentioned politician (see subsection 3.3). Berlusconi's language summarizes many of the traits we analyzed in the previous subsections (Croci 2011; Jačová 2011; Lyttleton 2009). He contributed to modifying the political agenda (particularly with respect to the conflict with the judiciary), and he was the first leader to create a 'personal party' and to take advantage of institutional changes and the personalization of politics to polarize and transform party competition in a referendum over himself. ${ }^{14}$ In addition, Berlusconi simplified 'political jargon' (politichese) and criticized the 'puppet theatre politics' (teatrino) of professional politicians. ${ }^{15}$

In light of the foregoing, we can check the correlation between word usage in post-1989 factional motions and Berlusconian language. We observed above that words such as magistratura, squadra and 
cambiamento are very common in both contexts. In Figure 9, we provide a more consistent assessment by focusing on a list of ten words typical of Berlusconi's language, drawn from the previous literature (Bolasco et al. 2006). Five of them are selected from the most 'peculiar' words, i.e., words that are more frequent in Berlusconi's lexicon than in the standard Italian lexicon and the journalistic jargon used in the 1990s by the newspaper 'La Repubblica' (Bolasco et al. 2006, 24). These words are 'freedom' (libertà), 'citizens' (cittadini), 'government' (governo), 'country' (paese), and 'we' (noi). The other five words are those that were most over-exploited by Berlusconi in his official role as prime minister when compared to other prime ministers of the Second Republic (Bolasco et al. 2006, 110). Among these words are 'everything' (tutto), 'our' (nostro), 'have' (avere), 'public' (pubblico), and 'opposition' (opposizione). We add certain other terms that are typical of Berlusconi's language, such as the three ' $i$ '-s - inglese, informatica, impresa ('English', 'Information Technology', 'enterprise') - and words included in catchphrases such as 'l'Italia che lavora e produce' (Italy that works and produces) and 'il governo del fare' (the government of doing).

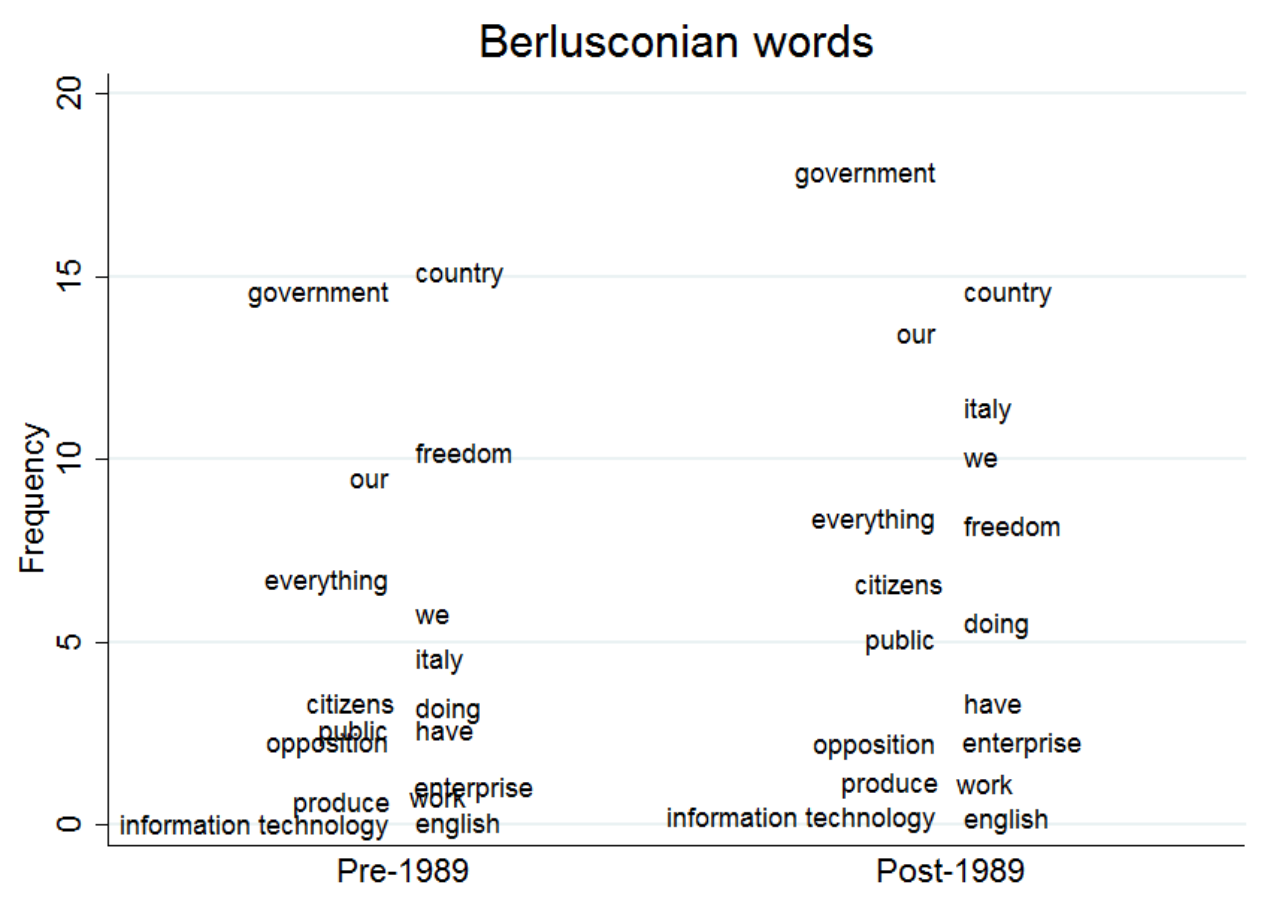

Figure 9. Normalized average frequency of 'berlusconian' words. Comparison between the first (pre-1989) and second periods (post-1989). 
Almost all of these words (14 out of 17) are used with a higher frequency after 1989. The only exceptions are libertà and paese, whose usage decreased, and opposizione, whose usage has remained constant. It is difficult to conclude whether Berlusconi contributed to altering the political discourse or instead emphasized an ongoing transformation of the political language. However, what emerges from this picture is a strong link between Berlusconi and Italian politics, given that in their internal debates, held after the transition, intra-party subgroups reverted to a growing usage of terms peculiar to Berlusconi's language.

3.7 Shift in the political meaning of words

To conclude, we analyze how the political meaning of some words has shifted. According to our analysis, during the Italian transition, some words shifted from the left to the right of the ideological scale (and vice versa). Some words that were commonly used by right-wing parties became peculiar to the left, while other words formerly characterizing left-wing parties are now used more frequently by the right. Figure 10 presents these changes and provides several examples, mostly related to words that have been previously discussed in the course of this article.

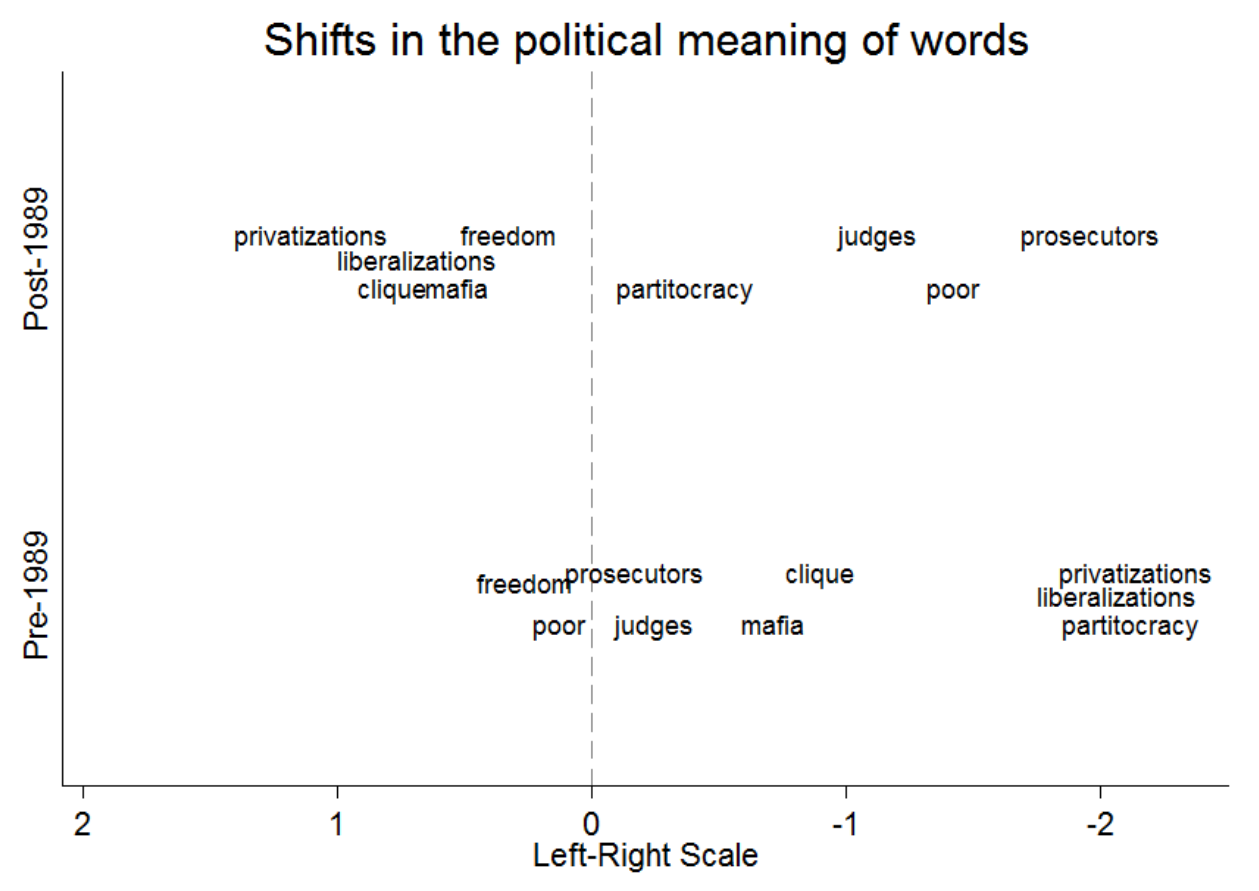

Figure 10. Variation in the placement of words along the left-right scale $(\beta)$. Differences between the first (pre-1989) and second periods (post-1989). 
As discussed above, the breakdown of communism restricted the domain of choices in the economic dimension and produced a process of 're-semanticisation' in which ideology became consensual in language (Hasan 2003). Based on this development, and as a consequence of the state's fiscal crisis, left-wing parties had to address liberal policies. References to 'privatizations' (privatizzazioni) and 'trade liberalizations' (liberalizzazioni) were the prerogative of the right before 1989, whereas left-wing parties began using them after 1989 as an attempt to distance themselves from the collectivistic policies supported in previous years. Other words have taken the reverse path. For instance, 'the poor' (bisognosi), a term frequently used by Berlusconi and the center-right parties, was mentioned mainly by the left before 1989. Similarly, use of the words 'judges' and 'prosecutors' (guidici and magistrati), which did not have political connotations, is currently peculiar to right-wing parties, evoking the conflict between the government and the judiciary (Ceron and Mainenti 2015). Conversely, mafia was a right-wing word used mainly by the MSI until 1989, whereas it later became the 'property' of the left. The usage of populist words also changed. Criticism of the words 'clique' (casta) and 'partitocracy' (partitocrazia) was a prerogative of the MSI before the transition, but these words were subsequently used by the left (casta) or uniformly by all parties (partitocrazia). This inquiry seems to suggest that the strategy of valence competition, which was mainly carried out by the antisystem Italian Social Movement throughout the First Republic, is now widely used by the left. ${ }^{16}$ Thus, this result can be considered evidence of the birth of a left-wing populism.

As a final point, we note that the word 'freedom' (libertà) has not changed meaning over time. Despite the fact that Berlusconi made extensive use of the term, which was always included in the name of the center-right coalition, the word 'freedom' is also mentioned by factions in centrist and left-wing parties and did not become the exclusive property of the right.

\section{Conclusion}

After the fall of the Berlin wall in 1989, several changes affected politics and language in Western democracies (Hasan 2003). Between 1989 and 1993, Italy experienced a transition from the First to the Second Republic, which consisted of institutional changes linked to electoral reforms as well as the personalization, 'mediatization' and 'presidentialization' of politics. These changes overlapped with a more 
general worldwide transformation in the style of political communication, which became more direct, simplified and focused on 'spectacularization' and on making increasing use of rhetoric and emotional and populist terms.

This paper employed a new dataset related to debates held during party congresses to measure how and to what extent institutional changes occurred in Italian politics after 1989, in addition to the evolution of political communication and the mediatization of politics, and how these subjects have altered the use of political language in internal party debates. We focused on changes that occurred in intra-party communications, i.e., when the party talks to itself such that the sender of the message (party leader or factions) nearly coincides with the addressee (party activists). Because these textual documents are addressed to party members and activists and not to the wide public of voters, we would not expect the declining role of ideology and the spectacularization and mediatization of political communication to affect the political language used by party factions (Ceron 2012).

By analyzing factional motions presented during party congresses through Wordfish, an automated technique of quantitative text analysis, we compared word usage before and after the beginning of the Italian transition and focused on the lexicon (changes in the relative frequencies of words over time) and acceptation (changes in the political meaning attached to words).

The analysis reveals that a few important changes occurred; these changes are consistent with previous literature. The lexicon was modified stylistically, with more references to emotional terms (Richards 2004), more rhetorical arguments, and the use of words such as 'new' and 'future' (Gualdo and Dell'Anna 2004). The lexicon has indeed been enriched with Anglophone words and with terms from other semantic fields, such as sports, war and religion (Jačová 2011; Lyttelton 2009; Semino and Masci 1996). The usage of terms related to topics such as Europe, justice and ecology has also grown (Bernardi and Tuzzi 2007; Jačová 2011). As such, intra-party documents track the evolution of the political agenda. New issues, such as Europeanization, the environment, devolution, and judiciary and institutional reforms, were also widely discussed after 1989. This point confirms how intra-party documents can be important to scholars aiming to analyze changes in the policy agenda (Baumgartner et al. 2006) and the emergence of new 
cleavages. The institutional reforms also altered the frequency of terms related to different political actors that have lost ('parliament') or gained ('government') relevance.

However, the language of intra-party politics has not changed dramatically. At least through 2010, the internal debates do not seem to have been affected by those changes in political communication that are closely related to the decline of ideology and the mediatization of politics. In fact, despite the growing personalization of politics, during post-1989 party congresses, party leaders have not been mentioned more often than their pre-1989 counterparts, except for Prodi and Berlusconi, the leaders of the two main coalitions. Both were mentioned remarkably more often than other politicians, which confirms how relevant they have been throughout the Second Republic. Analogously, the usage of populist words has not increased substantially.

Instead, we notice that references to ideologies persist, but the usage of 'socialism' and 'democracy' has decreased. However, this decrease is compensated for by a higher frequency of 'left' and 'right', words that are connoted by a clear ideological orientation. Although some authors have claimed that these two concepts are obsolete and faint (Giddens 1994), we showed that ideology and the left-right division are still relevant with respect to intra-party politics. After the 'death' of socialism and the end of the Cold War, parties still revert to ideological shortcuts through generic terms, such as 'left' and 'right', that are typically adopted by political scientists to denote the traditional ideological divide. In light of the foregoing, the limited changes in political language and the persistence of ideological references are good news for scholars who aim to estimate the position of political actors through automated techniques of text analysis applied to the internal documents of political parties.

In contrast with a more general trend revealed by other analyses, the phenomena of personalization and spectacularization have only marginally altered the political language within the party, and most of these changes are merely stylistic. When the party talks to itself to address members and activists, it still makes use of more traditional heuristics that lay far from the logic of entertainment.

1. See Shenhav and Sheafer (2008) for an analysis of changes in the media coverage of communications related to intraparty politics. 
2. Congresses that went unchallenged have been excluded from the analysis to focus only on those in which factions competed to win members' votes.

3. We analyzed all the motions related to contested congresses, retaining the text and excluding the signatures made by politicians who subscribed to the motion. All the words have been put into lowercase.

4. Wordfish has previously been applied to different text sources and contexts in several political systems, including Germany, the UK, the Netherlands and the European Union.

5. In party manifestos, factions or allies belonging to the same party/coalition frequently bargain over the inclusion of a single word.

6. See the newspaper 'La Repubblica', 15 August 2009.

7. Wordfish assumes that words follow a Poisson distribution, which is consistent with the literature on content analysis (for a review, see Slapin and Proksch 2008, 708). Being skewed, the Poisson is perfectly suited to analyze the distribution of words in text-based documents, which are also skewed, and this choice decreases computational costs. Nevertheless, Wordfish results are robust to the adoption of other distributions.

8. The Wordfish attempt to scale documents and words on an unobserved latent dimension stems from item response theory models. Thus, this method is not notably different from several alternatives, such as the Wordscores model (Lowe and Benoit 2011) or correspondence analysis (Benzécri 1992; Montali et al. 2013). The main distinction is that these techniques make different distributional assumptions because they assume a linear relationship between a word's position and the latent ideological placement of the text, whereas Wordfish assumes a log-linear relationship (Lowe and Benoit 2011, 5). In addition, Wordfish differs because it applies an iterative estimation process. Although other studies employed lexical correspondence analysis to track changes in language (Riva et al. 2008), we decided to utilize Wordfish because it is widely used in the large and growing literature on estimating the positions of political actors. Indeed, the results of the present work also speak to that literature given that the changes in political language over time have implications for the accuracy of those estimations.

9. Word frequencies have been normalized to account for the different total number of words used in the two periods. Using relative or absolute word frequencies, however, does not alter the results.

10. Note that this growth is not inflated by intra-party debates within the LN because this party was not included in the analysis.

11. An analysis of year-end speeches delivered by the Italian Head of State showed that references to words such as 'judges', ‘judiciary', and 'mafia' have increased since the 1980s (Bernardi and Tuzzi 2007).

12. The comparison has been performed considering words that stem from the following roots: elit*, consens*, antidemocratic $*$, referend $*$, corrot* $\left(\right.$ corrupt $\left.^{*}\right)$, propagand $*$, politici*, ingann* (decei*), tradi* $^{*}\left(\operatorname{treach}^{*}\right), \operatorname{vergogn}^{*}$ (shame*), scandal*, verità (truth), disonest* (dishonest*), partitocrazia (partitocracy), and menzogn* (lie*). This list was provided by Rooduijn and Pauwels (2011), and we added the word casta (clique) to it.

13. Note that these terms are also typical of Berlusconi's language (Croci 2001, 359-360). See subsection 3.6 for a deeper discussion of 'berlusconian' words.

14. Refer to Fetzer and Bull (2012) for a discussion regarding the language of leaders.

15. Note that both terms, politichese and teatrino, are classified as right-wing words in the analysis.

16. This is also consistent with the centrist drift of Italian left-wing parties after 1989, highlighted by the Wordfish analysis of party policy positions, that increased the incentives for valence competition (Curini and Martelli 2009). 


\section{References}

Baumgartner, Frank R., Christoffer Green-Pedersen, and Bryan D. Jones. 2006. "Comparative Studies of Policy Agendas." Journal of European Public Policy 13 (7): 959-74.

Bell, Daniel. 1988. "Afterword, 1988: The end of ideology revisited”. In The end of ideology (rev. ed.), ed. by Daniel Bell, 409 - 447. Cambridge, MA: Harvard University Press

Benzécri, Jean-Paul. 1992. Correspondence Analysis Handbook. New York, NY: Marcel Dekker.

Bernardi, Lorenzo, and Arjuna Tuzzi. 2007. "Parole lette con misura (statistica)". In Messaggi dal Colle $: i$ discorsi di fine anno dei Presidenti della Repubblica, ed. by Michele A. Cortelazzo, and Arjuna Tuzzi, 109134. Venezia: Marsilio.

Blumler, Jay G., and Dennis Kavangh. 1999. "The Third Age of Political Communication: Influences and Features." Political Communication 16 (3): 209-230.

Bolasco, Sergio, Luca Giuliano, and Nora Galli de' Paratesi. 2006. Parole in libertà. Un'analisi statistica e linguistica. Roma: Manifestolibri.

Bull, Martin J., and Martin Rhodes (eds). 1997. Crisis and Transition in Italian Politics. London: Frank Class.

Campus, Donatella. 2002. "Leaders, dreams and journeys: Italy's new political communication." Journal of Modern Italian Studies 7 (2): 171-191.

Campus, Donatella. 2010. "Mediatization and Personalization of Politics in Italy and France: The Cases of Berlusconi and Sarkozy.” The International Journal of Press/Politics 15 (2): 219-235.

Ceron, Andrea. 2012. "Bounded Oligarchy: How and When Factions Constrain Leaders in Party Positiontaking." Electoral Studies 31 (4): 689-701.

Ceron, Andrea. 2015. "The Politics of Fission: Analysis of Faction Breakaways among Italian Parties (19462011).” British Journal of Political Science 45 (1): 121-139. 
Ceron, Andrea, and Marco Mainenti. 2015. "Toga Party: The Political Basis of Judicial Investigations against MPs in Italy (1983-2013).” South European Society \& Politics 20 (2): 223-242.

Croci, Osvaldo. 2001. "Berlusconi's Triumph. Language and politics in Italy: from Moro to Berlusconi." Journal of Modern Italian Studies 6 (3): 348-370

Curini, Luigi, and Paolo Martelli. 2009. I partiti nella prima Repubblica. Maggioranze e governi dalla Costituente a Tangentopoli. Roma: Carocci.

della Porta, Donatella, and Manuela Caiani. 2006. "The Europeanization of Public Discourse in Italy. A TopDown Process?". European Union Politics 7 (1): 77-112.

Dyrberg, Torch B. 2003. "Right/left in the context of new political frontiers. What's radical politics today?" Journal of Language and Politics 2 (2): 333-360.

Fairclough, Norman. 2000. New Labour, New language? London: Routledge.

Fetzer, Anita, and Peter Bull. 2012. "Doing leadership in political speech: Semantic processes and pragmatic inferences." Discourse \& Society 23 (2): 127-144.

Fedel, Giorgio. 2003. "Parola mia. La retorica di Silvio Berlusconi”. Il Mulino 3: 463-473.

Franchino, Fabio, and Claudio M. Radaelli (eds). 2004. "Europeanisation and the Italian Political System: Politics and Policy.” Journal of European Public Policy 11 (6).

Fukuyama, Francis. 2006. The end of history and the last man. New York: Free Press.

Giddens, Anthony. 1994. Beyond Left and Right. The future of radical politics. Cambridge: Polity Press.

Gualdo, Riccardo, and Maria V. Dell'Anna. 2004. La faconda Repubblica. La lingua della politica in Italia (1992-2004). Lecce: Manni.

Hasan, Ruquaiya. 2003. "Globalization, literacy and ideology.” World Englishes 22 (4): 433-448

Jačová, Zora. 2011. “Il linguaggio politico della Seconda Repubblica.” Linguistica Pragensia 21 (1): 33-46. 
Lowe, Will, and Kenneth Benoit. 2011. "Estimating Uncertainty in Quantitative Text Analysis." Paper presented at the Annual Conference of the Midwest Political Science Association, 31 March-April 3 2011, Chicago.

Lyttelton, Adrian. 2009. "Political language in Italy and Great Britain." Journal of Modern Italian Studies 14 (1): 66-74.

Mazzoleni Gianpietro. 1987. "Media Logic and Party Logic in Campaign Coverage: The Italian General Election of 1983." European Journal of Communication 2 (1): 81-103

Mazzoleni, Gianpietro. 1991. "Emergence of the candidate and political marketing: Television and election campaigns in Italy in the 1980s." Political Communication 8 (3): 201-212.

Mazzoleni, Gianpietro, and Winfried Schultz. 1999. "Mediatization of Politics: A Challenge for Democracy?” Political Communication 16 (3): 247-261

McCarthy, Patrick. 1997. "Italy: a new language for a new politics?” Journal of Modern Italian Studies 2 (3): 337-357.

Montali, Lorenzo, Paolo Riva, Alessandra Frigerio, and Silvia Mele. 2013. "The representation of migrants in the Italian press. A study on the Corriere della Sera (1992-2009).” Journal of Language and Politics 12 (2): 226-250.

Patterson, Thomas E. 1993. Out of order. New York: Knopf.

Proksch, Sven-Oliver, and Jonathan B. Slapin. 2009. WORDFISH: Scaling Software for Estimating Political Positions from Texts. Version 1.3 (22 January 2009), http://www.wordfish.org.

Richards, Barry. 2004. "The Emotional Deficit in Political Communication.” Political Communication 21 (3): 339-352.

Riva, Paolo, Monica Colombo, and Lorenzo Montali. 2008. “Comparing Right and Left-wing discourse on immigration: a lexical correspondence analysis of Italian parliamentary debates.” Paper presented at the $9^{\text {th }}$ Journées internationales d'Analyse statistique des Données Textuelles. 
Rooduijn, Matthijs, and Teun Pauwels. 2011. "Measuring Populism: Comparing Two Methods of Content Analysis." West European Politics 34 (6): 1272-1283.

Semino, Elena, and Michela Masci. 1996. "Politics is Football: Metaphor in the Discourse of Silvio Berlusconi in Italy”. Discourse \& Society 7 (2): 243-269.

Shenhav, Shaul R., and Tamir Sheafer. 2008. "From Inter-Party Debate to Inter-Personal Polemic: Media Coverage of Internal and External Party Disputes in Israel, 1949 -2003.” Party Politics 14 (6): 706-725

Slapin, Jonathan B., and Sven-Oliver Proksch. 2008. "A scaling model for estimating time-series party positions from texts.” American Journal of Political Science 52 (3): 705-722.

\section{Author's address}

Andrea Ceron

Università degli Studi di Milano

Dipartimento di Scienze Sociali e Politiche

Via Passione 13, 20122 Milano

Italy

E-mail: andrea.ceron@unimi.it

\section{About the author}

Andrea Ceron is assistant professor at the Department of Social and Political Sciences, Università degli Studi di Milano, Milan. His research focuses on intra-party politics, quantitative text analysis, social media and political trust. His recent publications include, amongst others, articles in the British Journal of Political Science, European Journal of Political Research, Journal of Computer-Mediated Communication, New Media \& Society, International Journal of Press/Politics and Party Politics. See: http://andreaceron.com 